\title{
Genetic Mapping of the Rhodopseudomonas capsulata Chromosome Shows Non-clustering of Genes Involved in Nitrogen Fixation
}

\author{
By JOHN C. WILLISON, * GABRIEL AHOMBO, \\ JACQUELINE CHABERT, JEAN-PIERRE MAGNIN \\ AND PAULETTE M. VIGNAIS \\ Laboratoire de Biochimie Microbienne (CNRS UA 513), \\ Département de Recherche Fondamentale, Centre d'Etudes Nucléaires de Grenoble, $85 X$, \\ 38041 Grenoble Cedex, France
}

(Received 19 March 1985; revised 7 July 1985)

The mutant $\mathrm{R}$ plasmid pTH10 was used to construct a circular linkage map of the Rhodopseudomonas capsulata B10 chromosome. Mutations affecting nitrogen fixation (nif mutations) were dispersed in several groups on the chromosome. Biochemical analysis of nif mutants allowed identification of the structural gene for the nitrogenase component II or $\mathrm{Fe}$ protein (nif $H$ ) and a putative regulatory gene, possibly nif $A$. These two genes appeared closely linked in conjugation experiments, but represented two distinct linkage groups in crosses mediated by gene transfer agent. Other mutants were affected in the synthesis and/or stability of the nitrogenase component I or MoFe protein; synthesis of component II was also affected, but to a lesser extent. In two of these mutants, nitrogenase activity and the content of component I was increased five- to sixfold by the addition of $1 \mathrm{~mm}$-molybdate to the growth medium.

\section{INTRODUCTION}

The photosynthetic, purple, non-sulphur bacteria, in common with many other bacterial species, are able to fix $\mathrm{N}_{2}$. When derepressed for nitrogenase synthesis in the absence of $\mathrm{N}_{2}$, cultures of purple, non-sulphur bacteria show a light-dependent evolution of $\mathrm{H}_{2}$, a reaction that occurs at particularly high rates in Rhodopseudomonas capsulata (Hillmer \& Gest, 1977; Jouanneau et al., 1982). Nitrogenase synthesis in $R$. capsulata is repressed by $\mathrm{NH}_{4}^{+}$and by $\mathrm{O}_{2}$; nitrogenase activity is also inhibited by $\mathrm{NH}_{4}^{+}$, as in other purple, non-sulphur bacteria, by a mechanism involving reversible covalent modification of the Fe protein [see Vignais et al. (1985) for a review].

As part of the study of the regulation of $\mathrm{N}_{2}$ fixation and of $\mathrm{H}_{2}$ production in $R$. capsulata, we wished to determine the organization of the genes involved in $\mathrm{N}_{2}$ fixation and to identify regulatory genes. The organization and regulation of $\mathrm{N}_{2}$ fixation (nif) genes has been studied in most detail in Klebsiella pneumoniae. Between 12 and 14 nif genes have been identified in addition to the structural genes for nitrogenase, nif $H, D$ and $K$, which code respectively for component II, also known as the Fe protein, and for the $\alpha$ and $\beta$ subunits of component I, the MoFe protein (Roberts \& Brill, 1981; Dixon, 1984). These genes are clustered in a $24 \mathrm{~kb}$ region of the chromosome, and are organized in seven or eight transcriptional units or operons. The regulatory genes nif $L$ and nif $A$ form one of these operons: the nif $L$ gene product has a repressor function and may be involved in $\mathrm{O}_{2}$ regulation, while the nif $A$ gene product is required for the expression of all other nif operons. Regulation of nif $L A$ gene expression by fixed $\mathrm{N}$ is mediated by the unlinked $\mathrm{N}_{2}$ regulation (ntr) genes which also regulate other genes involved in $\mathrm{N}$ metabolism (Magasanik, 1982; Ausubel, 1984; Dixon, 1984).

Abbreviations: Cma, chromosome-mobilizing ability; GTA, gene transfer agent. 
Although a similar number of genes is probably involved in $\mathrm{N}_{2}$ fixation in other organisms, relatively little is known about their organization. The nif $H, D$ and $K$ genes, and in some cases nif $V$ or nif $S$, have been cloned from a number of bacteria by exploiting their homology with the corresponding genes from $K$. pneumoniae. These and neighbouring genes have been physically mapped in Anabaena sp. 7120 (Rice et al., 1982), in several Rhizobium species (Ruvkun \& Ausubel, 1981; Elmerich et al., 1982; Corbin et al:: 1983; Downie et al., 1983; Scott et al., 1984; Fischer \& Hennecke, 1984; Weinman et al., 1984) and in Azotobacter chroococcum (Jones et al., 1984). These studies have revealed differences in the organization and transcription of nif genes from that observed in $K$. pneumoniae. However, the presence of nif coding regions in the vicinity of the nitrogenase structural genes is frequently observed.

Among the purple, non-sulphur bacteria, genetic studies of $\mathrm{N}_{2}$ fixation have been restricted to $R$. capsulata, although $\mathrm{Nif}^{-}$mutants of some other species have been isolated (see Vignais et al., 1985). The cloned nifHDK genes of $R$. capsulata are contiguous and transcribed in a single operon, as in $K$. pneumoniae (Avtges et al., 1983). A $20 \mathrm{~kb}$ fragment of $R$. capsulata DNA has been isolated which contains several nif genes, although their function has not been identified (Pühler et al., 1984). Finally, by analysing $\mathrm{Nif}^{-}$mutants with gene transfer agent (GTA), a transduction-like system specific to $R$. capsulata, it has been possible to identify six linkage groups of nif mutations; however, the distance between these linkage groups could not be established (Wall \& Braddock, 1984; Wall et al., 1984).

In the present study, we have used $\mathrm{R}$ plasmid-mediated conjugation to construct a genetic map of the $R$. capsulata chromosome and to determine the approximate location of the nif genes. In parallel, we have biochemically analysed $\mathrm{Nif}^{-}$mutants in order to obtain information on the function of the different nif genes. The results indicate that the nif genes are dispersed in at least four or five groups on the $R$. capsulata chromosome.

\section{METHODS}

Bacterial strains and plasmids. All the $R$. capsulata mutants were derived from the wild-type strain B10. However, the laboratory strain of B10 differed from the originally isolated strain (Marrs, 1974) in being a poor producer of GTA. Only strains derived from the His- mutant J50 (obtained from Dr J. D. Wall, Department of Biochemistry, University of Missouri, USA) were good producers of GTA. The Nif- mutants RC1 to RC35 have been described previously (Willison \& Vignais, 1982). The nif or $n t r$ allele numbers assigned to these mutants are the same as the strain number. Other strains and the plasmids used in this study are listed in Table 1.

Media and growth conditions. $R$. capsulata strains were grown and maintained as described previously (Willison, \& Vignais, 1982). The minimal medium was RCV medium (Weaver et al., 1975: Hillmer \& Gest, 1977) containing either $30 \mathrm{mM}$-DL-malate or $30 \mathrm{~mm}$-DL-lactate as carbon source and $7.5 \mathrm{~mm}-\left(\mathrm{NH}_{4}\right)_{2} \mathrm{SO}_{4}$ as $\mathrm{N}$ source. $\mathrm{N}$-free medium was prepared by omitting the $\left(\mathrm{NH}_{4}\right)_{2} \mathrm{SO}_{4}$. Growth factors for auxotrophs were added at the following concentrations : amino acids and nucleotide bases, $20 \mu \mathrm{g} \mathrm{ml}^{-1}$; biotin, $50 \mathrm{ng} \mathrm{ml}^{-1}$. The complex medium used was YPS medium (Weaver et al., 1975) supplemented with $20 \mu \mathrm{g}$ tryptophan $\mathrm{ml}^{-1}$. Escherichia coli strains were grown in L-broth (Lennox, 1955), or in L-medium containing VB salts medium (Vogel \& Bonner, 1956) instead of $\mathrm{NaCl}$, and solidified with $1.5 \%(\mathrm{w} / \mathrm{v})$ agar. Liquid cultures were grown aerobically at $30^{\circ} \mathrm{C}$, in $10 \mathrm{ml}$ capacity stoppered tubes containing 3 to $5 \mathrm{ml}$ medium agitated in a rotary shaker. Growth was followed by measuring the $\mathrm{OD}_{660}$. The number of viable cells (c.f.u.) was determined by serially diluting the culture in dilution buffer (RCV medium without $\mathrm{C}$ or $\mathrm{N}$ source) and spreading $0.1 \mathrm{ml}$ samples on agar plates. In exponential phase cultures, an $\mathrm{OD}_{660}$ of 1.0 corresponded to approx. $3 \times 10^{8}$ c.f.u. $\mathrm{ml}^{-1}$.

Isolation of auxotrophs. Wild-type or auxotrophic strains were mutagenized with $N$-methyl- $N^{\prime}$-nitro- $N$ nitrosoguanidine (NTG) (Willison \& Vignais, 1982) or ethyl methanesulphonate (Meynell \& Meynell, 1970) and grown photosynthetically to early stationary phase in YPS medium. The cultures were diluted 10-fold in RCV medium, supplemented with the growth requirements of the parental strain, and incubated in the light until the $\mathrm{OD}_{660}$ had doubled ( 2 to $3 \mathrm{~h}$ ). The cells were then washed three times by centrifugation and resuspension in the same volume of RCV medium, diluted 10-fold in appropriately supplemented RCV medium, and incubated in the light until the culture became slightly turbid (4 to $6 \mathrm{~h}$ ). Penicillin $\mathrm{G}$ was then added to a final concentration of $100 \mathrm{U} \mathrm{ml}^{-1}$ and incubation continued for $24 \mathrm{~h}$. The penicillin-treated cells were washed three times in RCV medium, diluted 10- to 100-fold and spread on YPS agar plates. Auxotrophs $(0.1$ to $1 \%$ of survivors) were identified by replica-plating of colonies after 2 to $3 \mathrm{~d}$ aerobic growth in the dark. The nutritional requirements of auxotrophic strains were subsequently identified by streaking onto media containing different combinations of growth factors, as described by Holliday (1956). 
Isolation of carotenoidless mutants. Mutants affected in carotenoid biosynthesis ( $\mathrm{Crt}^{-}$) were obtained after NTG mutagenesis by plating appropriate dilutions of an early stationary phase culture onto YPS agar medium, and inspecting plates after 3 to $4 \mathrm{~d}$ aerobic incubation in the dark for colonies with altered pigmentation. Such colonies were observed at a frequency of 0.05 to $0.1 \%$.

Isolation of Nif- mutants. AP1, like strains AP29 and AP31, is a spontaneous mutant isolated from an N-limited continuous culture (P. Allibert, personal communication). Nif- derivatives of strain $\mathrm{J} 50$ were isolated as described previously (Willison \& Vignais, 1982) by spreading cultures onto RCV agar medium containing $7 \mathrm{~mm}$ $\mathrm{L}$-glutamate as major $\mathrm{N}$ source and supplemented with $20 \mu \mathrm{g}$ histidine $\mathrm{ml}^{-1}$ and $200 \mu \mathrm{M}$-metronidazole. Between 200 and 500 metronidazole-resistant colonies appeared per $10^{8}$ c.f.u. plated, of which 50 to $100 \%$ were $\mathrm{Nif}^{-}$, irrespective of whether the culture had been treated with mutagen or not (cf. Wall et al., 1984). This contrasted with the behaviour of strain B10, which yielded $<2 \% \mathrm{Nif}^{-}$colonies in the absence of treatment with mutagen.

Isolation of spontaneous antibiotic-resistant mutants. Cultures grown to early stationary phase were plated on RCV or YPS agar medium containing streptomycin $\left(100 \mu \mathrm{g} \mathrm{ml}^{-1}\right)$, rifampicin $\left(40 \mu \mathrm{g} \mathrm{ml}^{-1}\right)$, erythromycin $\left(10 \mu \mathrm{g} \mathrm{ml}^{-1}\right)$ or novobiocin $\left(5 \mu \mathrm{g} \mathrm{ml}^{-1}\right)$. Only RCV medium was used for the isolation of erythromycin-resistant (Ery ${ }^{r}$ ) mutants, due to the slow growth of Ery strains on YPS medium. Antibiotic-resistant colonies appeared after 3 to $4 \mathrm{~d}$ aerobic incubation in the dark, at the following frequencies (per c.f.u. plated): $\operatorname{Str}^{\mathrm{r}}, 10^{-7}$ to $10^{-9} ; \mathrm{Rif}^{\mathrm{r}}, 10^{-6} ; \operatorname{Ery}^{\mathrm{r}}, 10^{-7}$; Nov ${ }^{r}, 10^{-6}$ to $10^{-7}$.

Construction of plasmid-bearing strains. Plasmids were transferred between strains of E. coli and $R$. capsulata, and between different $R$. capsulata strains, by conjugation on YPS agar medium. For interspecific crosses, donor and recipient cultures were grown aerobically to exponential phase $\left(2\right.$ to $3 \times 10^{8}$ c.f.u. $\left.\mathrm{ml}^{-1}\right)$ in complex medium at $30{ }^{\circ} \mathrm{C}$ and small samples (approx. $25 \mu \mathrm{l}$ ) mixed on the surface of a YPS agar plate. The drop was spread to cover an area of approx. $2 \mathrm{~cm}^{2}$, allowed to dry, and the plate incubated at $30^{\circ} \mathrm{C}$ in the dark for 16 to $24 \mathrm{~h}$. The resultant growth was scraped off the plate, resuspended in $1.5 \mathrm{ml}$ YPS medium, and $0.1 \mathrm{ml}$ samples of a $10^{-4}$ dilution were plated on either RCV agar medium containing $10 \mu \mathrm{g} \mathrm{kanamycin} \mathrm{ml}^{-1}$ (for transfer to $R$. capsulata) or L-agar medium containing $20 \mu \mathrm{g}$ kanamycin $\mathrm{ml}^{-1}$ and $200 \mu \mathrm{g}$ streptomycin $\mathrm{ml}^{-1}$ (for transfer to $E$. coli HB101). Different $R$. capsulata strains were crossed as above, except that cultures were generally grown overnight for 16 to $18 \mathrm{~h} . \mathrm{Km}^{r}$ colonies of $R$. capsulata were grown aerobically in the dark for 4 to $6 \mathrm{~d}$, and then purified on YPS agar medium containing $25 \mu \mathrm{g}$ kanamycin $\mathrm{ml}^{-1}$. The presence of other plasmid-encoded markers was tested on medium containing antibiotics at the following concentrations: for E. coli, $10 \mu \mathrm{g}$ tetracycline $\mathrm{ml}^{-1}$ and $25 \mu \mathrm{g}$ ampicillin $\mathrm{ml}^{-1}$; for $R$. capsulata, $1 \mu \mathrm{g}$ tretracycline $\mathrm{ml}^{-1}$ (the $\mathrm{R}$ plasmids used in this study did not confer ampicillinresistance to $R$. capsulata $\mathrm{B} 10$, for which the $\mathrm{MIC}$ was $<0 \cdot 1 \mu \mathrm{g} \mathrm{ml}^{-1}$ ).

Transfer of chromosomal markers by $R$ plasmids. The chromosome donor strains used in mapping experiments were generally auxotrophic and were counterselected on appropriately supplemented minimal medium. Donor and recipient strains were grown aerobically in YPS medium, except for strain G29, which was grown photosynthetically in RCV medium containing $12 \mathrm{mM}$-glutamine as major $\mathrm{N}$ source. A $1: 1$ mixture of YPS medium and dilution buffer, containing $10^{6}$ to $10^{8}$ donor c.f.u. $\mathrm{ml}^{-1}$ and $10^{7}$ to $10^{8}$ recipient c.f.u. $\mathrm{ml}^{-1}$, was plated in $0.1 \mathrm{ml}$ samples on $\mathrm{RCV}$ agar medium for the selection of prototrophic recombinants and on $\mathrm{N}$-free RCV medium for the selection of $\mathrm{Nif}^{+}$recombinants. When the $\mathrm{Crt}^{+}$phenotype was selected, plates were incubated in anaerobic jars illuminated from one side only, at a distance of $60 \mathrm{~cm}$, to minimize background growth of the recipient $\mathrm{Crt}^{-}$strain. Mixtures containing recipient or donor cells alone were plated out as controls. Recombinant colonies were grown for 3 to $4 \mathrm{~d}$ in the light, or for 4 to $6 \mathrm{~d}$ in the dark, and were tested for cotransfer of unselected markers. Donor cell markers reverted at rates between $10^{-8}$ and $10^{-9}$ per c.f.u.; recipient cell markers, unless otherwise stated, reverted at rates between $5 \times 10^{-7}$ and $10^{-8}$ per c.f.u. When antibiotic counterselection was used, e.g. for strain construction (see Table 1), crosses were done on YPS agar medium, and the suspension of the mating mixture plated, without dilution, on agar medium containing the appropriate antibiotic.

Complementation of $\mathrm{Nif}^{-}$mutants with pRPA8. Triparental matings between HB101(pRPA8), HB101(pRK2013) and $R$. capsulata $\mathrm{Nif}^{-}$strains were done as described above for interspecific mating, except that $10 \mu \mathrm{l}$ of each $E$. coli strain culture was mixed with $20 \mu \mathrm{l}$ of $R$. capsulata culture. Mating mixtures were diluted $10^{4-}$ fold and plated either on $\mathrm{N}$-free RCV agar medium or on RCV medium containing $1 \mu \mathrm{g}$ tetracycline $\mathrm{ml}^{-1}$.

Mapping by GTA. GTA-producing strains containing nif markers were constructed either by isolating Nifmutants of strain J50 (see above) or by transferring nif markers into strain JP22 by conjugation, as indicated in Table 1. In the latter case, mating was done on YPS agar medium and the His ${ }^{+} \mathbf{S t r}^{\mathbf{r}}$ recombinants were selected and screened for $\mathrm{Nif}^{-}$phenotype; nif markers were contransferred with his- $1^{+}$at a frequency of $0 \cdot 3$ to $1 \%$. GTAmediated crosses were done as described by Yen \& Marrs (1976). Streptomycin resistance (Str ${ }^{r}$ ) was used as the unlinked control marker in mapping experiments. Strr recombinants were selected on RCV agar medium overlaid, after $4 \mathrm{~h}$ preincubation in the dark, with $5 \mathrm{ml} \mathrm{RCV}$ soft agar $(0.6 \%, \mathrm{w} / \mathrm{v})$ containing sufficient streptomycin to give a final concentration on the plates of about $100 \mu \mathrm{g} \mathrm{ml}^{-1}$.

Agarose gel electrophoresis. Plasmids in E. coli and $R$. capsulata were visualized by a modification of the Eckardt procedure, as described by Rosenberg et al. (1982). 


\section{J. C. WILLISON AND OTHERS}

Table 1. Bacterial strains and plasmids

Strain Genotype or phenotype*

Comments and source/reference $†$

E. coli strains

TH471

HB 101

$$
\begin{aligned}
& \mathrm{F}^{-}, \mathrm{Thr}^{-} \mathrm{Leu}^{-} \mathrm{Thi}^{-} \text {ton } A \\
& \text { lac Y supE } \mathrm{pTH} 10
\end{aligned}
$$

\begin{tabular}{|c|c|}
\hline B10 & Wild-type \\
\hline J50 & his-I \\
\hline G29 & $g \ln A I$ \\
\hline BY 16510 & bchA165 crtB4 hsd-1 str-2 \\
\hline AP1 & $n i f-200$ \\
\hline AP29 & nif-201 \\
\hline AP31 & nif-202 \\
\hline $\mathrm{RCl}$ & $n i f-1(n i f H I)$ \\
\hline RC3 & nif-3 (nifH3) \\
\hline $\mathrm{RC} 4$ & nif-4 \\
\hline $\mathrm{RC7}$ & nif-7 \\
\hline $\mathrm{RC} 8$ & nif-8 (nifH8) \\
\hline RC9 & nif-9 (nifH9) \\
\hline $\mathrm{RC} 10$ & nif-10 \\
\hline $\mathrm{RC} 11$ & $\mathrm{Nif}^{-}$ \\
\hline $\mathrm{RC} 12$ & $\mathrm{Nif}^{-}$ \\
\hline $\mathrm{RC} 15$ & nif-15 \\
\hline RC16 & nif-16 \\
\hline $\mathrm{RC} 17$ & nif- 17 \\
\hline $\mathrm{RC} 18$ & nif- 18 \\
\hline $\mathrm{RC} 19$ & nif -19 \\
\hline $\mathrm{RC} 20$ & nif-20 \\
\hline $\mathrm{RC} 21$ & nif -21 \\
\hline $\mathrm{RC} 22$ & nif -22 \\
\hline $\mathrm{RC} 23$ & nif-23 \\
\hline $\mathrm{RC} 24$ & nif -24 \\
\hline RC26 & nif-26 \\
\hline $\mathrm{RC} 27$ & $n t r-27$ \\
\hline $\mathrm{RC} 28$ & $n t r-28$ \\
\hline $\mathrm{RC} 29$ & $n t r-29$ \\
\hline RC30 & $\mathrm{Nif}^{-}$ \\
\hline $\mathrm{RC} 31$ & $\mathrm{Nif}^{-}$ \\
\hline $\mathrm{RC} 32$ & nif -32 \\
\hline $\mathrm{RC} 33$ & nif-33 (nifH33) \\
\hline RC34 & $n t r-34$ \\
\hline RC35 & nif $f-35$ \\
\hline $\mathrm{RC} 37$ & Wild-type, pTH10 \\
\hline $\mathrm{RC} 38$ & Wild-type, RP1 \\
\hline RC39 & $i l v-10$ \\
\hline $\mathrm{RC} 42$ & ade-1 \\
\hline RC58 & crt-4 \\
\hline $\mathrm{RC} 92$ & $u r a-2$ \\
\hline RC94 & bio-2 \\
\hline RC98 & $i l v-10$ str-6 \\
\hline RC99 & $i l v-10$ nov-1 \\
\hline $\mathrm{RC} 100$ & ilv-10 rif-1 \\
\hline $\mathrm{RC} 101$ & ilv-10 rif-l, pТН 10 \\
\hline $\mathrm{RC} 102$ & ilv -10 rif-1, RP1 \\
\hline $\mathrm{RC} 103$ & ilv-l0 rif-I str-1, $\mathrm{TTH} 10$ \\
\hline $\mathrm{RC} 126$ & ilv-I0 rif-1 str-1, $\mathrm{pTH} 10$ \\
\hline $\mathrm{RC} 134$ & $t y r-1$ \\
\hline $\mathrm{RC} 135$ & tyr-I ery-I \\
\hline $\mathrm{RC} 138$ & tyr-1 ery-1 nov-9, рТН10 \\
\hline $\mathrm{RC} 149$ & tyr-1 rif-1 str-I \\
\hline $\mathrm{RC} 160$ & ade-1 tyr-I, рТН 10 \\
\hline $\mathrm{RC} 168$ & ade-1 ura-1 rif-1 str-1, pTH10 \\
\hline
\end{tabular}

$\mathrm{F}^{-}, \operatorname{rec} A$ Pro
$\operatorname{rps} L$ supE
Harayama et al. (1980)

Boyer \& Roulland-Dussoix (1969)

Marrs (1974); Weaver et al. (1975)

Genthner \& Wall (1984)

Wall \& Gest (1979); Scolnik et al. (1983)

Taylor et al. (1983)

P. Allibert, Centre d'Etudes Nucléaires, Grenoble

Allibert et al. (1984)

Allibert et al. (1984)

Willison \& Vignais (1982)

Willison \& Vignais (1982)

Willison \& Vignais (1982); 'leaky'

Willison \& Vignais (1982)

Willison \& Vignais (1982)

Willison \& Vignais (1982)

Willison \& Vignais (1982); 'leaky'

Willison \& Vignais (1982); 'leaky'

Willison \& Vignais (1982); 'leaky'

Willison \& Vignais (1982)

Willison \& Vignais (1982)

Willison \& Vignais (1982)

Willison \& Vignais (1982)

Willison \& Vignais (1982)

Willison \& Vignais (1982)

Willison \& Vignais (1982)

Willison \& Vignais (1982)

Willison \& Vignais (1982)

Willison \& Vignais (1982)

Willison \& Vignais (1982)

Willison \& Vignais (1982)

Willison \& Vignais (1982)

Willison \& Vignais (1982)

Willison \& Vignais (1982); 'leaky'

Willison \& Vignais (1982); 'leaky'

Willison \& Vignais (1982)

Willison \& Vignais (1982)

Willison \& Vignais (1982)

Willison \& Vignais (1982)

Derived from B10 by conjugation with $E$. coli $\mathrm{TH} 471$

Derived from B10 by conjugation with $E$. coli HB101(RP1)

Derived from B10 by NTG

Derived from B 10 by NTG

Blue-green mutant, derived from B10 by NTG

Derived from B10 by NTG

Derived from B10 by NTG

Spontaneous derivative of RC39

Spontaneous derivative of RC39

Spontaneous derivative of RC39

Derived from RC100 by conjugation with RC37

Derived from RC100 by conjugation with RC38

Spontaneous derivative of RC101

Spontaneous derivative of $\mathrm{RC} 103$ with increased Cma

Derived from LS10 by GTA

Spontaneous derivative of RC134

Derived from RC135 by conjugation with GA100

Derived from $\mathrm{RC} 134$ by conjugation with $\mathrm{RC} 126$

Derived from LS10 by conjugation with $\mathrm{RC} 126$

Derived from LS8 by conjugation with $\mathrm{RC} 103$ 


\section{Table 1 (continued)}

\begin{tabular}{|c|c|}
\hline Strain & Genotype or phenotype* \\
\hline $\begin{array}{l}\mathrm{RC} 183 \\
\mathrm{RC} 188 \\
\mathrm{RC} 189 \\
\mathrm{RC} 192\end{array}$ & $\begin{array}{l}\text { his-I, nif- } 85, \text { рТН } 10 \\
\text { his-I nif- } 85 \text { str- } 14 \\
\text { his- } 1 \text { nif- } 88 \text { str- } 14 \\
\text { his-I trp- } 1, \text { pTH10 }\end{array}$ \\
\hline $\begin{array}{l}\text { GA100 } \\
\text { GA108 } \\
\text { GA111 } \\
\text { GA120 } \\
\text { GA143 }\end{array}$ & $\begin{array}{l}\text { ilv- } 10 \text { nov }-1 \text {, } \mathrm{pTH} 10 \\
\text { his }-1 \text { nif }-85 \\
\text { his }-1 \text { nif- } 88 \\
\text { ilv- } 10 \text { rif- } 1 \text { crt }-10, \text { pTH } 10 \\
\text { his- } 1 \text { nif- } 88 \text { crt }-13\end{array}$ \\
\hline $\begin{array}{l}\text { JP1 } \\
\text { JP13 } \\
\text { JP16 } \\
\text { JP22 } \\
\text { JP26 } \\
\text { JP27 } \\
\text { JP28 }\end{array}$ & $\begin{array}{l}\text { nif-1, } \mathrm{pTH} 10 \\
\text { nif-3, } \mathrm{pTH} 10 \\
\text { nif-16, } \mathrm{pTH} 10 \\
\text { his-1 } \\
\text { nif-1 } \\
\text { nif- } 14 \\
\text { nif- } 3 \text { str-14 } \\
\text { nif-16 } \text { str-14 }\end{array}$ \\
\hline $\begin{array}{l}\text { LS2 } \\
\text { LS6 } \\
\text { LS8 } \\
\text { LS10 } \\
\text { LS16 } \\
\text { LS27 } \\
\text { LS29 }\end{array}$ & $\begin{array}{l}\text { his-1 trp-I } \\
\text { his-1 ade-2 } \\
\text { ade-1 ura-1 } \\
\text { ade-1 tyr-1 } \\
\text { ser-1 } \\
\text { leu-3 } \\
\text { leu-4 }\end{array}$ \\
\hline $\begin{array}{l}\text { Plasmids } \\
\text { pTH10 }\end{array}$ & $K m^{r} T c^{r}\left(A p^{r}\right)$ \\
\hline RP1 & $K m^{r} \operatorname{Tc}^{r}\left(A p^{r}\right)$ \\
\hline $\begin{array}{l}\text { pRK292 } \\
\text { pRK2013 }\end{array}$ & $\begin{array}{l}\mathrm{Tc}^{\mathrm{r}} \\
\mathrm{K} \mathrm{m}^{\mathrm{r}}\end{array}$ \\
\hline pRPA8 & $\mathrm{Te}^{r}$ \\
\hline
\end{tabular}

Comments and source/reference $\dagger$

Derived from GA108 by conjugation with GA100

Derived from GA108 by GTA

Derived from GA111 by GTA

Derived from LS2 by conjugation with GA100

Derived from RC 99 by conjugation with RC37

Derived from $\mathbf{J} 50$ by EMS

Spontaneous derivative of $\mathrm{J} 50$

Blue-green mutant, derived from RC392 by NTG

Orange mutant, derived from GA111 by NTG

Derived from $\mathrm{RCl}$ by conjugation with $\mathrm{RC} 101$

Derived from $\mathrm{RC} 3$ by conjugation with $\mathrm{RC} 101$

Derived from $\mathrm{RC} 16$ by conjugation with $\mathrm{RC} 101$

Spontaneous derivative of $\mathrm{J} 50$

Derived from JP22 by conjugation with JP1

Derived from JP22 by conjugation with JP13

Derived from JP22 by conjugation with JP16

Derived from $\mathbf{J} 50$ by NTG

Derived from J50 by NTG

Derived from $\mathrm{RC} 42$ by NTG

Derived from RC42 by NTG

Derived from B10 by NTG

Derived from B10 by NTG

Derived from B10 by NTG

Mutant of RP4 temperature-sensitive for maintenance in E. coli; Harayama et al. (1980)

Wild-type plasmid, probably identical to RP4; Burkardt et al. (1979)

Plasmid vector; Avtges et al. (1983)

Mobilizing plasmid; Ditta et al. (1980)

$R$. capsulata nifHDK genes clone in HindIII site of pRK292; Avtges et al. (1983)

* E. coli gene symbols are as defined by Bachmann \& Low (1980). $R$. capsulata markers are abbreviated as follows. Biosynthetic markers : ade, adenine; $b c h$, bacteriochlorophyll; bio, biotin; $c r t$, carotenoids; his, histidine; $i l v$, isoleucine and valine; leu, leucine; ser, serine; trp, tryptophan; tyr, tyrosine; ura, uracil. Chromosomal antibiotic-resistance markers : ery, erythromycin; nov, novobiocin; rif, rifampicin; str, streptomycin. Others: $h s d$, host-specific defence; nif, $\mathrm{N}_{2}$ fixation; ntr, $\mathrm{N}$ regulation. Plasmid markers: $\mathbf{A p}^{r}$, ampicillin resistance; $\mathbf{K m}^{r}$, kanamycin resistance; $\mathrm{Tc}^{\mathrm{r}}$, tetracycline resistance.

$\dagger$ 'By NTG' and 'by EMS' refer to mutagenesis with $N$-methyl- $N$ '-nitro- $N$-nitrosoguanidine or with ethyl methanesulphonate, respectively. Cma, chromosome-mobilizing ability (Holloway, 1979).

Biochemical techniques. Nitrogenase activity in vivo was assayed in resting cell suspensions as described previously (Willison \& Vignais, 1982). Cell-free extracts for the determination of nitrogenase activity were prepared from 1-1 cultures and assayed for activity and protein content as described previously (Hallenbeck $e t$ al., 1982). Immunological assay of nitrogenase polypeptides was done on crude cell-free extracts which were prepared either as above, or by a small-scale method from $10 \mathrm{ml}$ cultures (Jouanneau et al., 1985), and centrifuged for $1 \mathrm{~min}$ at $15 \mathrm{lbf} \mathrm{in-2}(103.5 \mathrm{kPa})$ in a Beckman air-driven centrifuge to remove membrane fragments. Immunodiffusion was done on microscope slides coated with $3 \mathrm{ml} \mathrm{1 \%}$ agarose dissolved in Tris/barbiturate buffer, pH 8.6 (LKB). Wells of $2 \mathrm{~mm}$ diameter were punched in a rosette configuration in the gel, $10 \mu \mathrm{l}$ antiserum against either component I ( RcI) or component II (RcII) of $R$. capsulata nitrogenase was placed in the central well and $10 \mu \mathrm{l}$ of crude extract ( 5 to $10 \mu \mathrm{g}$ protein) in each of the six peripheral wells. Immunodiffusion was done overnight at ambient temperature, and the precipitin arcs stained with Coomassie Blue R250. Rocket immunoelectrophoresis (Laurell, 1965) was done on $10 \times 10 \mathrm{~cm}$ plastic sheets (LKB) coated with $10 \mathrm{ml} 1 \%$ agarose containing $80 \mathrm{~mm}$ Tris, $40 \mathrm{~mm}$-sodium acetate, $1 \mathrm{~mm}$-EDTA, $0.5 \mathrm{~mm}$-calcium lactate, $\mathrm{pH} 8.6$, and either $80 \mu \mathrm{l}$ anti-RcI serum or $160 \mu \mathrm{l}$ anti-RcII serum. Eight wells were punched in the gel and $10 \mu \mathrm{l}$ cell-free extract, diluted to contain 0.05 to $0.5 \mathrm{mg}$ protein $\mathrm{ml}^{-1}$, was placed in each well. After electrophoresis for $4 \mathrm{~h}$ at $2.5 \mathrm{~V} \mathrm{~cm}^{-1}$, gels were washed overnight in $0.1 \mathrm{M}-\mathrm{NaCl}$, dried, and stained with Coomassie Blue R250. Rocket area was determined by photographing the gel and cutting out and weighing the rockets. 


\section{RESULTS AND DISCUSSION}

\section{Behaviour of plasmid pTH10 in R. capsulata}

pTH 10 and the wild-type plasmid RP1 could be transferred from $E$. coli to $R$. capsulata B10 at frequencies of up to $2 \times 10^{-2}$ per recipient c.f.u. plated. Both plasmids conferred resistance in $R$. capsulata to kanamycin $\left(\mathrm{Km}^{\mathrm{r}}\right)$ and tetracycline $\left(\mathrm{Tc}^{\mathrm{r}}\right)$ but not to ampicillin $\left(\mathrm{Ap}^{\mathrm{r}}\right)$. In E. coli $\mathrm{K} 12$, the plasmid pTH10 is temperature-sensitive for maintenance, and is lost from cells grown at $42^{\circ} \mathrm{C}$ (Harayama et al., 1980). Temperature-resistant derivatives can arise by transposition of the $\mathrm{Ap}^{\mathrm{r}}$ gene $(\operatorname{Tn} l)$ into the chromosome, followed by integration of the plasmid at the site of insertion. Such derivatives function as Hfr strains, transferring the $E$. coli chromosome from an origin at the site of insertion (Harayama et al., 1980). In $R$. capsulata, however, pTH10 showed no evidence of temperature sensitivity or of integration into the chromosome, since the transfer frequency of pTH10 to other strains of $R$. capsulata was similar at $37^{\circ} \mathrm{C}$ and at $30^{\circ} \mathrm{C}$, no detectable loss of $\mathrm{Km}^{\mathrm{r}}(<0.1 \%)$ occurred after aerobic growth in YPS medium at $37^{\circ} \mathrm{C}$, and the intensity of the plasmid band corresponding to pTH10 was similar in agarose gels of cell lysates from cultures grown at either $30^{\circ} \mathrm{C}$ or $37^{\circ} \mathrm{C}$. (In E. coli TH471, this band was weak or undetectable when cultures were grown at $37^{\circ} \mathrm{C}$, and completely absent at $42{ }^{\circ} \mathrm{C}$.) Transfer of pTH10 from $R$. capsulata RC37 to $E$. coli HB101 showed that the plasmid had retained its temperature sensitivity in $E$. coli. A similar lack of phenotypic expression of temperaturesensitive plasmids, including pTH10, has been reported for other Gram-negative bacteria (Hooykaas et al., 1982).

Although the lack of temperature sensitivity of pTH10 in $R$. capsulata precluded the direct selection of $\mathrm{Hfr}$ strains, pTH 10 was able to transfer chromosomal markers at frequencies as high as $5 \times 10^{-3}$ per donor cell (see below), whereas RP1 transferred the same markers at frequencies of $10^{-8}$ to $10^{-9}$. The mechanism of chromosome mobilization in $R$. capsulata by pTH10 is unknown. It has been suggested that the low frequency of chromosome mobilization by RP1 in $E$. coli, like the integration of pTH10 into the chromosome, is due to transposition of $\mathrm{Tn} I$ (Harayama et al., 1980, 1981). It is possible, therefore, that the frequency of transposition of Tnl into the $R$. capsulata chromosome is greater in strains carrying pTH10 than in strains carrying RP1. Surprisingly, not all $\mathrm{Km}^{r}$ exconjugants containing $\mathrm{pTH} 10$ showed chromosomemobilizing ability (Cma), as many as five in six colonies tested in each cross being $\mathrm{Cma}^{-}$. However, after subsequent isolation and purification, $\mathrm{Cma}$ was maintained stably in positive strains (see below).

\section{Characteristics of chromosome mobilization by pTH10}

All genetic markers tested were transferred, at frequencies ranging from $10^{-6}$ to $2 \times 10^{-4}$ per donor c.f.u. plated (transfer frequencies for a given marker varied up to fivefold between experiments and were roughly proportional to donor cell concentration in the range $10^{6}$ to $10^{7}$ donor c.f.u. per $0.1 \mathrm{ml}$ plated). In crosses between the strains $\mathrm{RC101}$ and $\mathrm{RCl}$, the transfer frequency of nif-1+ $\left(4 \times 10^{-5}\right.$ to $1 \times 10^{-6}$ per donor c.f.u. plated) and the coinheritance frequency of rif- 1 ( $5.5 \pm 2.8 \%$ in 12 determinations), appeared to be independent of the growth phase of the donor and recipient strains, the growth medium (RCV or YPS) and growth conditions (aerobic or photosynthetic) of the recipient strain. Transfer and coinheritance frequencies were decreased twofold by washing the cells before mating, and up to 10-fold when mating was done on YPS agar medium or on freshly poured plates. The mating procedure described for Rhodopseudomonas sphaeroides (Sistrom, 1977) gave no improvement in conjugation efficiency over the method described here.

Donor strains of $R$. capsulata showed no detectable loss of Cma after being subcultured several

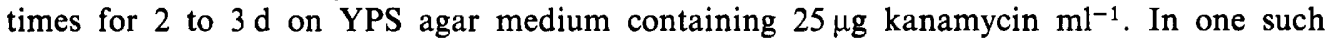
experiment, a derivative of RC103, strain RC126, was isolated which showed greatly increased transfer frequency of markers in region I of the chromosome map (see Fig. 1 and below), and increased coinheritance frequencies of these markers. For example, the transfer frequency of nif $-1^{+}$was proportional to the donor cell concentration in the range $10^{4}$ to $10^{5}$ donor c.f.u. per $0.1 \mathrm{ml}$ plated, reaching a maximum value of $5 \times 10^{-3}$ per donor c.f.u., and the rif- 1 allele was 


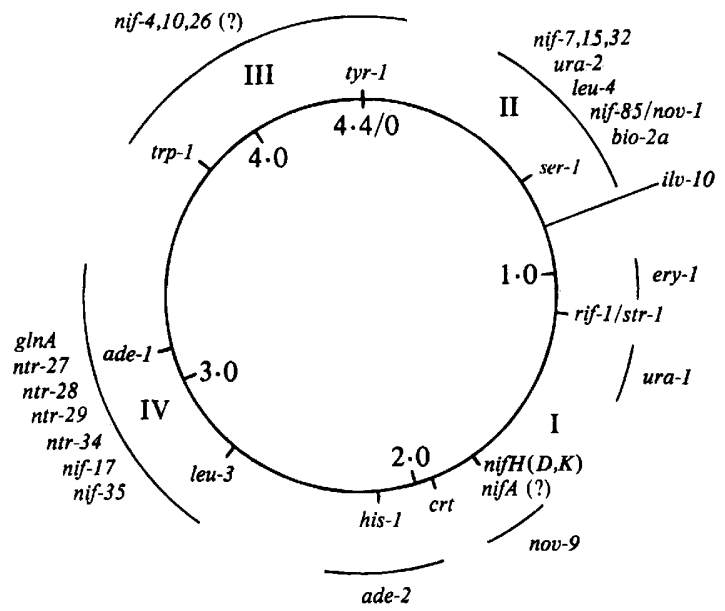

Fig. 1. Circular linkage map of the $R$. capsulata chromosome. The map was constructed from data obtained in pTH10-mediated crosses (see Table 2, Fig. 2 and text), but excluding data obtained in crosses with $\mathrm{RC} 126$ as donor strain. The distance between genetic markers was calculated by assuming that $d=1-c^{1 / 3}$ where $c$ is the coinheritance ratio and $d$ is the map distance in arbitrary units (Kondorosi et al., 1977). The scale of distance is marked inside the circle, with the position of the $t y r-1$ locus being arbitrarily chosen as zero. The markers used to establish circularity of the chromosome (Table 2) are positioned on the circle itself, while the $i l v$ - 10 locus is shown joined by a radial line to the circle, since the distance between the ser- 1 and $i l v-10$ loci has not been established directly. The approximate position of other markers is shown outside the circle. Roman numerals indicate the four regions of the chromosome defined by their linkage to antibiotic-resistance determinants (see text).

contransferred at a frequency of 20 to $35 \%$. Agarose gel electrophoresis showed that pTH10 was still present in the autonomous state in strain $\mathrm{RC126}$, although this does not preclude the presence of a copy of the plasmid integrated in the chromosome. The enhanced Cma of strain $\mathrm{RC} 126$ appeared to be due to a host mutation rather than a plasmid mutation, since strains that had received pTH10 by conjugation from $\mathrm{RC} 126$ did not show enhanced Cma.

\section{Mapping of the R. capsulata chromosome}

A circular linkage of the $R$. capsulata chromosome (Fig. 1) was established by pTH10mediated conjugation, using the data given in Table 2 and below. Auxotrophic donor strains containing pTH 10 were counterselected on minimal medium, and selection was made for transfer of if $^{+}$or biosynthetic markers. The apparent cotransfer frequency of unselected donor markers, e.g. antibiotic-resistance markers was then determined by replica plating. Attempts to select directly for transfer of antibiotic-resistance markers (either chromosomal or plasmid coded), using the method for transfer of $\operatorname{Str}^{r}$ by GTA, were unsuccessful, even when up to $8 \mathrm{~h}$ was allowed for phenotypic expression before addition of antibiotic to the selective medium. It is noteworthy that the chromosomal genes conferring resistance to rifampicin, streptomycin and erythromycin were closely linked, and two genes conferring resistance to novobiocin were identified (Fig. 1).

When each of a given pair of markers could be selected for, the two values for the cotransfer frequency of the unselected marker, expressed as a percentage, generally differed by less than $5 \%$. An exception was the marker pair his $-1^{+} /$ade $-2^{+}$, since when selection was made for $\mathrm{His}^{+}$, the mean cotransfer frequency of $\mathrm{Ade}^{+}$was $61.4 \%$, whereas when selection was made for $\mathrm{Ade}^{+}$, the mean cotransfer frequency of $\mathrm{His}^{+}$was only $14.1 \%$ (see Fig. 1). This difference was not due to a difference in plating efficiency of $\mathrm{Ade}^{+}$and $\mathrm{His}^{+}$recombinants, which was $>90 \%$ in both cases. A possible explanation for the difference in cotransfer frequency is that ade-2+ could be transferred in a polar fashion from an origin located between the two markers. The overall pattern of transfer frequencies and linkage relationships suggests that transfer of the $R$. capsulata chromosome occurs from several origins. 


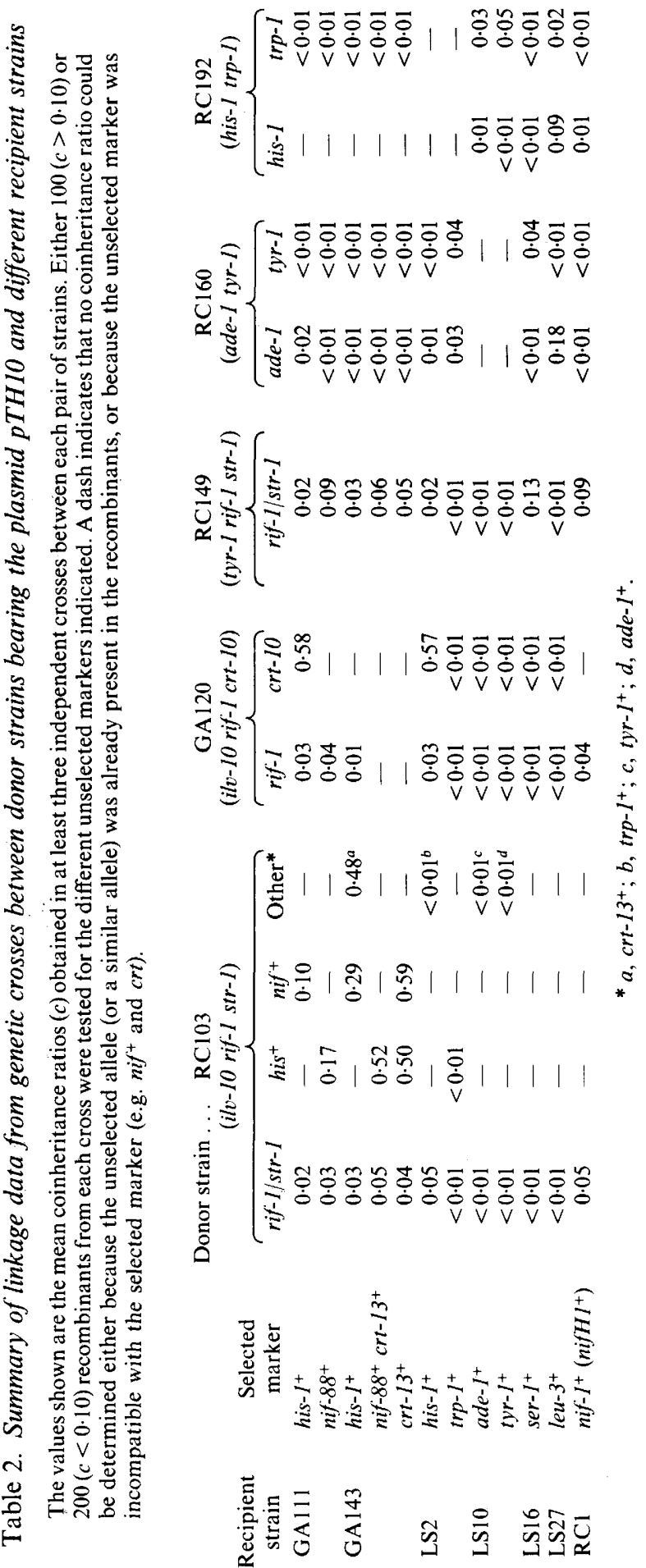


(a)

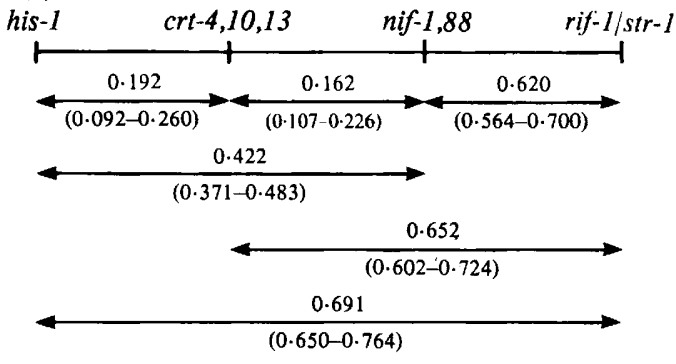

(b)

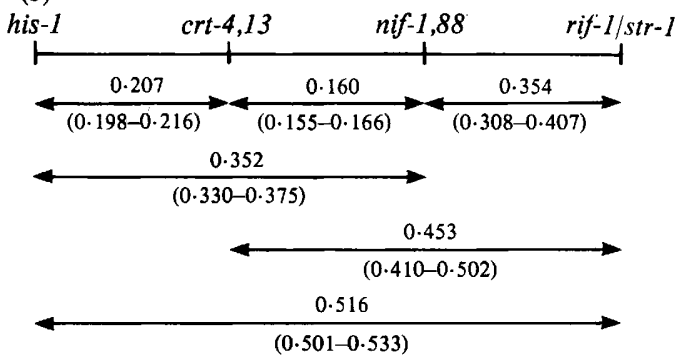

(c)

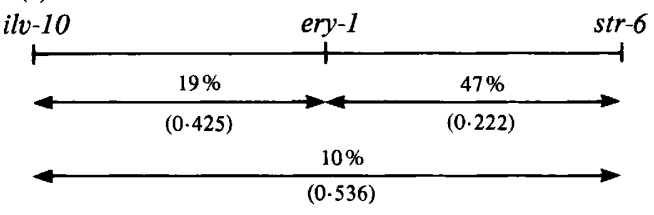

(d)

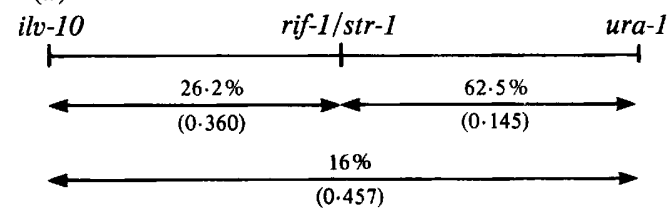

Fig. 2. Gene order and additive map distances in region $I$ of the $R$. capsulata chromosome. (a) Summary of data from crosses between the donor strains RC103 and GA120, and the recipient strains $\mathrm{RC1}$, RC58, GA111 and GA143 with selection being made for $\mathrm{His}^{+}, \mathrm{Crt}^{+}$or $\mathrm{Nif}^{+}$( $\mathrm{NB}$ in crosses with GAl43, the $\mathrm{Nif}^{+}$phenotype could not be selected independently of $\mathrm{Crt}^{+}$). The values shown are the map distances in arbitrary units, calculated from the mean coinheritance ratio \pm SE. (b) As $(a)$, but with RC126 as the donor strain. (c) Results of a single cross between strains RC138 and RC98, with selection being made for Ilv $\mathrm{v}^{+}$. The percentage coinheritance of unselected markers is shown, with the calculated map distance in parentheses; $47 \%$ of $\mathrm{Ilv}^{+} \mathrm{Ery}^{\mathrm{r}}$ recombinants were $\mathrm{Str}^{\mathrm{s}}$, whereas $90 \% \mathrm{of}_{\mathrm{Ilv}}^{+} \mathrm{Str}^{\mathrm{s}}$ were Eryr $^{r}$. (d) As (c), but for a cross between strains RC168 and RC39. All Ilv ${ }^{+} \operatorname{Str}^{r}$ recombinants were Rif $^{r}$; $62.5 \%$ of $\mathrm{Ilv}^{+} \operatorname{Str}^{r} \mathrm{Rif}^{\mathrm{r}}$ were Ura ${ }^{-}$, whereas $100 \%$ of $\mathrm{Ilv}^{+} \mathrm{Ura}^{-}$were $\mathrm{Rif}^{\mathrm{r}}$ and $\mathrm{Str}^{\mathrm{r}}$.

The map distances used in Fig. 1 were calculated by using a relationship derived for generalized transduction which is also applicable to plasmid R68.45-mediated conjugation in Rhizobium meliloti (Kondorosi et al., 1977). In the latter case, large fragments of the chromosome are transferred from several points of origin. The data in Fig. 2 show that map distances calculated this way were approximately additive, at least for cotransfer frequencies greater than $10 \%$. Analysis of mapping data was complicated by apparent variations in recombination frequency between certain markers. Thus, strain $\mathrm{RC126}$ gave greatly increased cotransfer 
frequencies compared to other donor strains (compare Fig. $2 a$ with Fig. $2 b$ ), and with some pairs of markers (e.g. ade- $2^{+} /$his $-1^{+}$and $h i s-1^{+} /$crt-13+) cotransfer frequencies of $100 \%$ were sometimes observed. This could be due either to variations in the absolute frequency of recombination between cotransferred markers, or to variations in cotransfer frequency, with little or no recombination occurring between closely linked markers. The following observations support the latter explanation: $(a)$ the increased cotransfer frequencies obtained with strain $\mathrm{RC} 126$ were correlated with an increase in the absolute transfer frequency of the markers concerned; (b) markers in region II of the chromosome (Fig. 1) appeared to be unlinked to the rif- 1 and str- 1 markers when the donor strain contained the ilv-10 allele, but showed coinheritance of these markers when the donor strain was $i l v-10^{+}$, suggesting that little or no recombination occurs between the region II markers and ilv-10. Nevertheless, in crosses between $\mathrm{RC} 126$ and GA111, up to $50 \%$ of $\mathrm{His}^{+} \mathrm{Str}^{\mathrm{r}}$ recombinants were $\mathrm{Nif}^{-}$, suggesting either that crossing over does occur (between his-1 and nif-88 and between nif-88 and str-1) or that his- $1^{+}$and rif- 1 can be transferred independently to the same recipient cell.

\section{Organization and function of $\mathrm{N}_{2}$ fixation genes}

Groups $I-A$ and $I-B$. A large number of nif mutations mapped in region I of the chromosome. These mutations were characterized by a high degree of linkage ( $>20 \%$ cotransfer) to rif- 1 and $s t r-1$ in crosses with RC126, and were closely linked to the photosynthetic gene cluster, which contains the genes for carotenoid, bacteriochlorophyll and reaction centre biosynthesis (Fig. 1; cf. Yen \& Marrs, 1976; Youvan et al., 1982), and were also linked to a gene coding for histidine biosynthesis. The linkage between the his-l and nif- 88 markers in strain GA111 was variable, being as high as $30 \%$ when RC126 was the donor strain (see Fig. 2) and as low as $1 \%$ when either $\mathrm{RC} 138$ or RC192 was the donor. The proximity of the nif-1, nif-3 and nif-8 alleles to the photosynthesis genes was confirmed by crossing strains JP1, JP13 and JP16 with strain BY16510, and selecting $\mathrm{Crt}^{+} \mathrm{Bch}^{+} \mathrm{Str}^{\mathrm{r}}$ recombinants. In each case, between $30 \%$ and $50 \%$ of such recombinants were $\mathrm{Nif}^{-}$and had therefore received the donor nif allele. Finally, the wildtype alleles of all the mutations assigned to group I showed 28 to $37 \%$ coinheritance of nov-9 and 6 to $16 \%$ coinheritance of ery-1 in crosses with RC138 as donor strain.

The group I mutations were analysed in more detail with GTA (Fig. 3). They fell into two linkage groups (I-A and I-B) that are separated by at least 2700 bp (cf. Wall \& Braddock, 1984). Group I-A mutants RC1, RC3, RC8 and RC33 were devoid of component II protein and contained variable amounts of active component $\mathrm{I}$; in strain RC9, component II protein was present, but inactive (Table 3). We were unable to reproduce previous experiments that showed RC9 to have a low, but detectable nitrogenase activity (Willison \& Vignais, 1982). The Nif ${ }^{-}$ phenotype of these mutants (but not that of group I-B mutants) was complemented by pRPA8, which contains the $R$. capsulata nif $H D K$ genes. Group I-A mutations are therefore located in the nif $H$ gene.

The group I-B mutants comprised 7 of 10 mutants isolated previously by direct plating onto RCV agar medium containing glutamate and metronidazole (Willison \& Vignais, 1982), 23 of 24 mutants, including some spontaneous mutants, isolated in the present study by the same method, and 2 of 3 spontaneous mutants isolated from $\mathrm{N}$-limited continuous culture. (Strains RC23 and AP31, which mapped in group I by conjugation, showed a similar phenotype to the group I-B mutants, but gave very low numbers of $\mathrm{Nif}^{+}$recombinants in GTA-mediated crosses, and also failed to revert; they may therefore contain more than one nif mutation, or a deletion.) These mutants lacked detectable nitrogenase activity, as assayed by acetylene reduction, and were devoid of both nitrogenase components (data not shown). They appeared to be specifically affected in $\mathrm{N}_{2}$ fixation, since growth on other $\mathrm{N}$ sources and on low concentrations of $\mathrm{NH}_{4}^{+}$ ( $<2 \mathrm{mM}$ ) was unaffected. Moreover, strains AP29 and AP31 contain normal levels of the $\mathrm{NH}_{4}^{+-}$ assimilating enzymes glutamine synthetase and glutamine:oxoglutarate aminotransferase (Allibert et al., 1984). Wall et al. (1984) have described a similar group of mutations that appear spontaneously in malate/glutamate medium and can be selected with metronidazole. Most of these mutations mapped in a single linkage group, which was different from the five nif linkage 

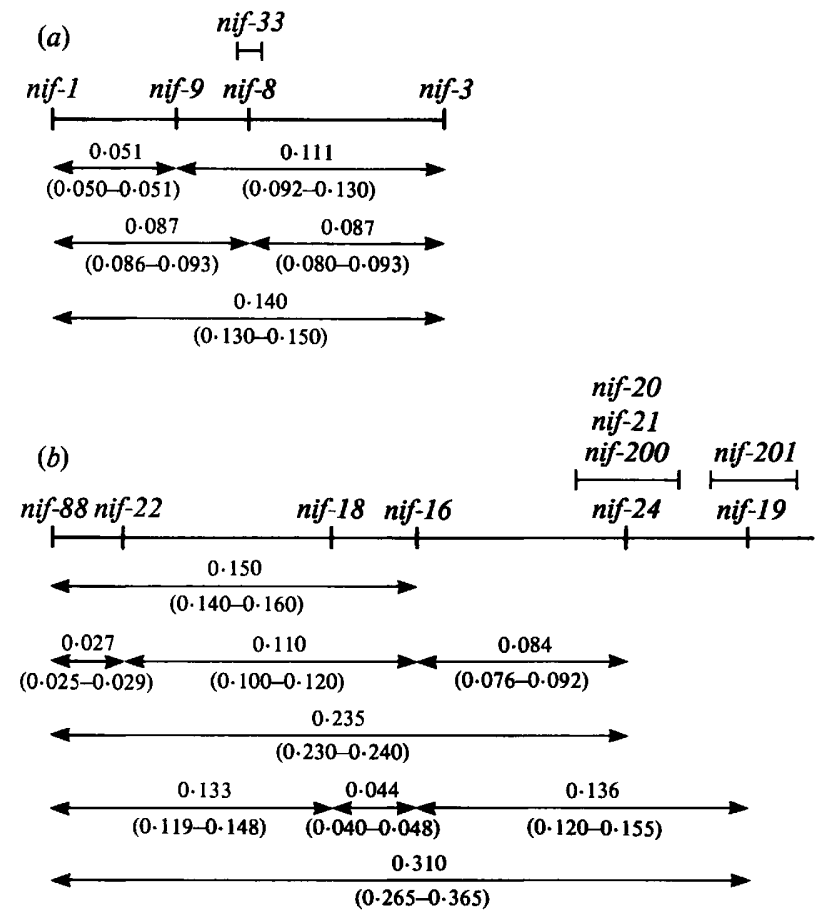

Fig. 3. Fine-structure mapping of nif mutations in region I of the $R$. capsulata chromosome. (a) Group I-A (nifH); (b) group I-B (nif $A$-like gene). GTA-mediated crosses were done as described in Methods, using the donor strains JP26 (nif-1), JP27 (nif-3), JP28 (nif-16) and RC189 (nif-88), all of which contained the str-14 allele. The values shown are map distances, calculated as described by Yen $\&$ Marrs (1976), with the 95\% confidence intervals in parentheses (Kimball, 1961). A map distance of 1.0 unit is equivalent to 4600 bp (Taylor et al., 1983). The two groups of mutations showed no significant linkage to each other, and are therefore separated by at least 2700 bp (Wall \& Braddock, 1984).

groups described previously (Wall \& Braddock, 1984). These mutations appear to be located in a regulatory gene (or genes) that affects the expression of the nifHDK operon, and therefore resembles the nif $A$ gene of $K$. pneumoniae. However, it remains to be determined whether the mutations in this gene affect the expression of nif genes other than the structural genes for nitrogenase.

Groups $I I-A$ and $I I-B$. The wild-type alleles of the biosynthetic markers in region II of the chromosome showed 5 to $57 \%$ coinheritance of nov-1 in crosses with GA100 as donor strain, and were linked to rif- 1 and str-1 (5 to $22 \%$ coinheritance) only in crosses with strains that did not contain the $i l v-10$ allele, i.e. RC149 and RC168. Four nif mutations mapped in this region, and could be divided into two groups (II-A and II-B) on the basis of their linkage to nov-1. Group IIA was represented by a single mutation, nif- 85 , the wild-type allele of which was linked $50 \%$ to nov-1. Since the apparent transfer frequency of nif- $85^{+}\left(7.6 \times 10^{-5}\right.$ per recipient c.f.u. $)$ was only twice the spontaneous reversion rate $\left(3.9 \times 10^{-5}\right)$, the true coinheritance frequency was probably closer to $100 \%$. In crosses with strain RC183 as donor, the leu-4+, ser $-1^{+}, u r a-2^{+}$and bio- $2 a^{+}$alleles showed 20 to $73 \%$ coinheritance of nif- 85 , and the coinheritance of $i l v-10^{+}$and nif85 was $93 \%$.

The wild-type group II-B alleles, nif- $7^{+}$, nif- $15^{+}$and nif-32+, showed 1 to $8 \%$ coinheritance of nov-1, a lower frequency than that observed for other markers in region II of the chromosome. However, the predicted linkage of these markers to tyr-1 could not be demonstrated, since no $\mathrm{Nif}^{+}$recombinants could be obtained in crosses between $\mathrm{RC1} 60($ tyr- 1$)$ and the group II-B Nif ${ }^{-}$ mutants. Finally, GTA-mediated crosses between strain RC188 (nif-85) and strains RC7, RC15 and $\mathrm{RC} 32$ provided no evidence for linkage between the two groups of mutations. 
Table 3. Nitrogenase activity and nitrogenase component concentrations in crude extracts of wild-type and Nif- strains

Crude extracts containing 10-1000 $\mu$ g protein were assayed for nitrogenase activity as described in Methods, and titrated with purified RcI or RcII until no further increase in activity was observed. The concentration of nitrogenase components was determined by rocket immunoelectrophoresis, with samples containing 1-10 $\mu \mathrm{g}$ protein, and using purified RcI and RcII as standards. The molecular weight of the nitrogenase component was taken to be 230000 for RcI and 63000 for RcII (Hallenbeck $e t$ al., 1982). Nitrogenase activities and concentrations varied by less than twofold between different cultures of the same strain (cf. Willison \& Vignais, 1982); the values shown are the mean determination on extracts from two or three separate cultures. ND, Not determined.

\begin{tabular}{|c|c|c|c|c|c|c|}
\hline \multirow[b]{2}{*}{$\begin{array}{l}\text { Mutant } \\
\text { group }\end{array}$} & \multirow[b]{2}{*}{ Strain } & \multicolumn{3}{|c|}{ 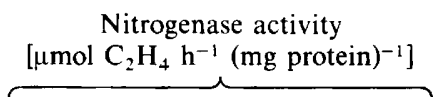 } & \multicolumn{2}{|c|}{$\begin{array}{c}\text { Concentration of } \\
\text { nitrogenase components } \\
{\left[\text { nmol }(\mathrm{mg} \text { protein })^{-1}\right]}\end{array}$} \\
\hline & & $\begin{array}{c}\text { No } \\
\text { addition }\end{array}$ & $+\mathrm{RcI}$ & $+\mathrm{RcII}$ & RcI & RcII \\
\hline Wild-type & B 10 & 3.96 & $5 \cdot 59$ & $20 \cdot 0$ & $1 \cdot 18$ & $2 \cdot 13$ \\
\hline I-A & $\begin{array}{l}\mathrm{RCl} \\
\mathrm{RC} 3 \\
\mathrm{RC} 8 \\
\mathrm{RC} 9 \\
\mathrm{RC} 33\end{array}$ & $\begin{array}{l}<0.01 \\
<0.01 \\
<0.01 \\
<0.01 \\
<0.01\end{array}$ & $\begin{array}{c}<0.01 \\
<0.01 \\
<0.01 \\
<0.01 \\
\quad \text { ND }\end{array}$ & $\begin{array}{l}5 \cdot 02 \\
0 \cdot 89 \\
4 \cdot 14 \\
6 \cdot 16 \\
\text { ND }\end{array}$ & $\begin{array}{r}0.39 \\
0.10 \\
0.23 \\
0.32 \\
<0.04\end{array}$ & $\begin{array}{r}<0.08 \\
<0.08 \\
<0.08 \\
0.57 \\
<0.08\end{array}$ \\
\hline II-B & $\begin{array}{l}\mathrm{RC} 7 \\
\mathrm{RC} 15 \\
\mathrm{RC} 32\end{array}$ & $\begin{array}{l}0 \cdot 06 \\
0 \cdot 05 \\
0 \cdot 14\end{array}$ & $\begin{array}{l}0 \cdot 29 \\
0 \cdot 37 \\
0 \cdot 90\end{array}$ & $\begin{array}{l}0 \cdot 89 \\
1 \cdot 00 \\
1 \cdot 20\end{array}$ & $\begin{array}{l}0.05 \\
0.07 \\
0.07\end{array}$ & $\begin{array}{l}0.43 \\
0.41 \\
0.48\end{array}$ \\
\hline III & $\begin{array}{l}\text { RC4 } \\
\text { RC10 }\end{array}$ & $\begin{array}{l}0.69 \\
0.07\end{array}$ & $\begin{array}{l}1.07 \\
0.35\end{array}$ & $\begin{array}{l}3.69 \\
0 \cdot 64\end{array}$ & $\begin{array}{l}0.63 \\
0.27\end{array}$ & $\begin{array}{l}1.83 \\
1.97\end{array}$ \\
\hline
\end{tabular}

Biochemical analysis showed that strain GA108 lacked detectable nitrogenase activity and was devoid of both nitrogenase components (data not shown), whereas the group II-B mutants, although deficient in both components, were more deficient in component I than in component II (Table 3). Titration of crude extracts with purified nitrogenase components (Table 3 ) showed that both components in group II-B mutants were catalytically active. It is probable that the group II-B mutations are located in a gene (or genes) affecting the synthesis and/or stability of component I, and that synthesis and/or stability of component II is affected indirectly. Like group I and group III mutants, these mutants appeared to be unaffected in the utilization of $\mathbf{N}$ sources other than $\mathrm{N}_{2}$.

Group III. Strains RC4, RC10 and RC26 were slightly 'leaky' for growth on N-free RCV agar medium, but background growth was sufficiently low to allow the visualization of $\mathrm{Nif}^{+}$ recombinants. The nif-4, nif- 10 and nif-26 mutations were tentatively localized in region III of the chromosome, since like tyr- 1 and trp- 1 they showed no linkage either to nov- 1 in crosses with GA100, or to rif- 1 and str-I in crosses with RC126. However, we were unable to detect linkage between these markers and the $t y r-1$ and $\operatorname{trp}-1$ alleles, possibly because of competition for the tyrosine or tryptophan added to the medium between any auxotrophic $\mathrm{Nif}^{+}$transconjugants and the background growth of the $\mathrm{Nif}^{-}$recipient strain. An extrachromosomal location for these mutations therefore cannot be excluded.

In crude extracts of strain RC4, the specific nitrogenase activity was about $20 \%$ of that found in the wild-type strain, but the level of component I was about $50 \%$, and the level of component II between 65 and $85 \%$ of that in the wild-type (Tables 3 and 4 ). However, although titrations with purified component II indicated that component I is less active in the mutant than in the wild-type, titration with purified component I failed to stimulate nitrogenase activity to a level consistent with the immunologically determined content of component II (Table 3).

Strains RC10 and RC26 differed from other strains tested in that nitrogenase activity in derepressed cultures was stimulated five- to sevenfold by the addition of $1 \mathrm{~mm}$-molybdate to the growth medium; addition of molybdate resulted in an approx. sixfold increase in the level of nitrogenase component I, but had little or no effect on the content of component II (Table 4). These mutants are clearly affected in the utilization of molybdate for incorporation into the 
Table 4. Effect of molybdate on in vivo nitrogenase activity and nitrogenase component concentration in wild-type and Nif strains

\begin{tabular}{|c|c|c|c|c|c|}
\hline \multirow{2}{*}{\multicolumn{6}{|c|}{$\begin{array}{l}\text { Strains were grown photosynthetically for } 40 \mathrm{~h} \text { in } 10 \mathrm{ml} \text { volumes of RCV n } \\
\mathrm{NH}_{+}^{+} \text {as } \mathrm{N} \text { source, with or without addition of } 1 \mathrm{mM} \text {-sodium molybdate. Re } \\
\text { were prepared from these cultures and assayed for nitrogenase activity a } \\
\text { respectively, as described in Methods and the legend to Table } 3 \text {. The } \\
\text { determination on two or three separate cultures; nitrogenase activities an } \\
\text { strain varied up to twofold between different cultures (cf. Willison } \\
\text { determined. }\end{array}$}} \\
\hline & & & & & \\
\hline group & Strain & molybdate & $\left.(\mathrm{mg} \text { cell dry wt })^{-1}\right]$ & RcI & RcII \\
\hline Wild-type & B 10 & - & $\begin{array}{l}1.98 \\
1.66\end{array}$ & $\begin{array}{l}0.87 \\
0.66\end{array}$ & $\begin{array}{l}1.97 \\
2.35\end{array}$ \\
\hline II-B & $\mathrm{RC} 32$ & $\bar{t}$ & $\begin{array}{l}<0.01 \\
<0.01\end{array}$ & $\begin{array}{c}0.07 \\
\text { ND }\end{array}$ & $\begin{array}{c}0.57 \\
\text { ND }\end{array}$ \\
\hline III & $\begin{array}{l}\mathrm{RC} 4 \\
\mathrm{RC} 10 \\
\mathrm{RC} 26\end{array}$ & $\begin{array}{l}- \\
+ \\
- \\
+ \\
- \\
+\end{array}$ & $\begin{array}{l}0.17 \\
0.14 \\
0.11 \\
0.77 \\
0.16 \\
0.87\end{array}$ & $\begin{array}{l}0.48 \\
0.40 \\
0.07 \\
0.47 \\
0.10 \\
0.61\end{array}$ & $\begin{array}{l}1.29 \\
1.08 \\
1.05 \\
1.38 \\
1.02 \\
1.22\end{array}$ \\
\hline IV & $\begin{array}{l}\mathrm{RC} 17 \\
\mathrm{RC} 34\end{array}$ & $\begin{array}{l}- \\
+ \\
+\end{array}$ & $\begin{array}{l}<0.01 \\
<0.01 \\
<0.01 \\
<0.01\end{array}$ & $\begin{array}{l}0.19 \\
0.22 \\
0.21 \\
0.28\end{array}$ & $\begin{array}{l}0.57 \\
0.51 \\
0.40 \\
0.63\end{array}$ \\
\hline
\end{tabular}

MoFe protein and phenotypically resemble the nif $Q$ mutants of $K$. pneumoniae (Imperial et al., 1984). The loss of function in these mutants results in a decrease in synthesis and/or stability of the MoFe protein.

Group IV. The markers in region IV of the chromosome were linked to ade-l (3 to $27.5 \%$ coinheritance) and to trp- 1 ( 2 to $19.5 \%$ coinheritance) but not to tyr-1, and showed linkage of 1 to $4 \%$ to rif- 1 and str- 1 in crosses with RC126. The Nif- mutants RC26, RC27, RC28 and RC34 were unable to utilize glutamate, proline, arginine or alanine as sole $\mathrm{N}$ source, but grew on glutamine with a long lag period and a doubling time of approx. $8 \mathrm{~h}$, compared to $2.2 \mathrm{~h}$ for the wild-type. The growth rate of these strains on $\mathbf{N H}_{4}^{+}$was similar to that of the wild-type, even at growth-rate-limiting concentrations $(<2 \mathrm{mM})$. The inability of these strains to utilize poor $\mathbf{N}$ sources other than $\mathrm{N}_{2}$ for growth, and their inability to derepress nitrogenase synthesis when grown with growth-limiting concentrations of $\mathrm{NH}_{4}^{+}$(Table 3; Willison \& Vignais, 1982) suggest that their mutations may be located in a gene (or genes) analogous to the nitrogen regulation (ntr) genes of $K$. pneumoniae (cf. Magasanik, 1982; Dixon, 1984).

In $K$. pneumoniae, the $n t r B$ and $n t r C$ genes form a complex operon with the structural gene for glutamine synthetase, $g \ln A$. In $R$. capsulata, the $g \ln A$ gene mapped in the same chromosome region as the ntr-type mutations. However, on the basis of the observed cotransfer frequencies, it appeared to be closer to trp-1 $(15.5 \%$ coinheritance vs $3 \%)$ and further from ade-1 $(3 \%$ coinheritance vs 7 to $13.5 \%$ ) than the ntr-type mutations.

Two other mutations affecting $\mathrm{N}_{2}$ fixation, nif-35 and nif-17, mapped in this region. The nif-35 mutation may not be a true nif mutation, since the derepressed level of nitrogenase activity in RC35 was similar to that of the wild-type, and in some experiments this strain was unable to form colonies on $\mathrm{RCV}$ agar plates containing $\mathrm{NH}_{4}^{+}$as $\mathrm{N}$ source. Strains $\mathrm{RC1} 1, \mathrm{RC1} 2, \mathrm{RC} 30$ and RC31 were similar to RC35 but presented a leaky Nif- phenotype and could not be used as recipients in genetic crosses. Strain RC17 resembled RC34 in containing equally decreased levels of both nitrogenase components (Table 4) but grew normally on all $\mathrm{N}$ sources tested, except $\mathrm{N}_{2}$. In $\mathrm{RC} 17$, as in the $\mathrm{Ntr}^{-}$and group II-B mutants, the nitrogenase activity relative to 
that of the wild-type was higher in vitro than in vivo (Willison \& Vignais, 1982; cf. Tables 2 and 3 ). The reason for this behaviour is not yet clear, although possible explanations include a deficiency in electron transport to nitrogenase, in vivo inhibition of nitrogenase activity, and modification of the kinetics of nitrogenase activity due to an alteration in the ratio of the nitrogenase components.

Mutations such as nif-17 and the group I-B and II-A mutations, which results in a co-ordinate decrease in synthesis of the two nitrogenase components, may be located in nif-specific regulatory genes, but might also occur in genes encoding cryptic functions that indirectly affect expression of the nitrogenase structural genes. Further studies are needed to distinguish between these two possibilities, e.g. by cloning the relevant genes and determining whether their expression is nif-specific, or subject to repression by $\mathrm{NH}_{4}^{+}$and/or by $\mathrm{O}_{2}$.

We thank P. Allibert and Drs B. A. Haddock, S. Harayama, R. Haselkorn, D. Helinski and J. D. Wall for generously providing strains, Laurence Sueur for isolating mutants and Dr Y. Jouanneau for providing antiserum and purified nitrogenase components. We are grateful to Jacqueline Roux for typing the manscript. This work was supported by research grants from the Centre National de la Recherche Scientifique (CNRS, APP PIRSEM).

\section{REFERENCES}

Allibert, P., Odom, J. M., Wall, J. D. \& Vignais, P. M. (1984). Phenotypic changes in hydrogen evolving chemostat cultures of Rhodopseudomonas capsulata. FEMS Microbiology Letters 23, 221226.

AUsubel, F. M. (1984). Regulation of nitrogen fixation genes. Cell 37, 5-6.

Avtges, P., Scolnik, P. A. \& Haselkorn, R. (1983). Genetic and physical map of the structural genes (nif $H, D, K)$ coding for the nitrogenase complex of Rhodopseudomonas capsulata. Journal of Bacteriology 156, 251-256.

BACHMANN, B. J. \& Low, K. B. (1980). Linkage map of Escherichia coli K-12, edn 6. Microbiological Reviews 44, 1-56.

Boyer, H. W. \& Roulland-Dussoix, D. (1969). A complementation analysis of the restriction and modification of DNA in Escherichia coli. Journal of Molecular Biology 41, 459-472.

Burkardt, H. J., Riess, G. \& PüHLER, A. (1979). Relationship of group $\mathrm{Pl}$ plasmids revealed by heteroduplex experiments: RP1, RP4, R68 and RK2 are identical. Journal of General Microbiology 114, 341-348.

Corbin, D., Barran, L. \& DitTa, G. (1983). Organization and expression of Rhizobium meliloti nitrogen fixation genes. Proceedings of the National Academy of Sciences of the United States of America 80, 30053009.

Ditta, G., Stanfield, S., Corbin, D. \& Helinski, D. R. (1980). Broad host range DNA cloning system for Gram-negative bacteria: construction of a gene bank of Rhizobium meliloti. Proceedings of the National Academy of Sciences of the United States of America 77, 7347-7351.

Dixon, R. A. (1984). The genetic complexity of nitrogen fixation. Journal of General Microbiology 130, 2745-2755.

Downie, J. A., MA, Q. S., Knight, C. D., НomBRECHER, G. \& JoHnston, A. W. B. (1983). Cloning of the symbiotic region of Rhizobium leguminosarum: the nodulation genes are between the nitrogenase genes and a nif $A$-like gene. EMBO Journal $2,947-$ 952.

Elmerich, C., Dreyfus, B. L., Reysset, G. \& Aubert,
J. P. (1982). Genetic analysis of nitrogen fixation in a tropical fast growing Rhizobium. EMBO Journal 1, 499-503.

Fischer, H. M. \& HeNNECKE, H. (1984). Linkage map of the Rhizobium japonicum nif $H$ and nif $D K$ operons encoding the polypeptides of the nitrogenase enzyme complex. Molecular and General Genetics 196, 537540.

GENTHNER, F. \& WALL, J. D. (1984). Isolation of a recombination-deficient mutant of Rhodopseudomonas capsulata. Journal of Bacteriology 160, 971975.

Hallenbeck, P. C., Meyer, C. M. \& Vignais, P. M. (1982). Nitrogenase from the photosynthetic bacterium Rhodopseudomonas capsulata: purification and molecular properties. Journal of Bacteriology 149, 708-717.

Harayama, S., Tsuda, M. \& Iino, T. (1980). High frequency mobilization of the chromosome of Escherichia coli by a mutant of plasmid RP4 temperature-sensitive for maintenance. Molecular and General Genetics 180, 47-56.

Harayama, S., Tsuda, M. \& IINo, T. (1981). Tn $I$ insertion mutagenesis in Escherichia coli $\mathrm{K} 12$ using a temperature-sensitive mutant of plasmid RP4. Molecular and General Genetics 184, 52-55.

Hillmer, P. \&. GeST, H. (1977). $\mathrm{H}_{2}$ metabolism in the photosynthetic bacterium Rhodopseudomonas capsulata: $\mathrm{H}_{2}$-production by growing cultures. Journal of Bacteriology 129, 724-731.

Holliday, R. (1956). A new method for the identification of biochemical mutants of micro-organisms. Nature, London 178, 987.

Holloway, B. W. (1979). Plasmids that mobilize bacterial chromosome. Plasmid 2, 1-19.

HooykaAs, P. J. J., Den Dulk-Ras, H. \& SchilperOORT, R. A. (1982). Phenotypic expression of mutations in a wide-host-range R-plasmid in Escherichia coli and Rhizobium meliloti. Journal of Bacteriology 150, 395-397.

Imperial, J., Ulgalde, R. A., Shah, V. K. \& Brill, W. J. (1984). Role of the nif $Q$ gene product in the incorporation of molybdenum into nitrogenase in Klebsiella pneumoniae. Journal of Bacteriology 158, 187-194. 
Jones, R., Woodley, P. \& Robson, R. (1984). Cloning and organization of some genes for nitrogen fixation from Azotobacter chroococcum and their expression in Klebsiella pneumoniae. Molecular and General Genetics 197, 318-327.

Jouanneau, Y., Willison, J. C., Colbeau, A., Hallenbeck, P. C., RiolacCi, C. \& Vignais, P. M. (1982). Enhancement of the photoproduction of $\mathrm{H}_{2}$ by Rhodopseudomonas capsulata: optimization in continuous cultures, role of uptake hydrogenase, genetic characterization and economic evaluation. In Photochemical, Photoelectrochemical and Photobiological Processes, Solar Energy Research and Development in the European Community, Series D, vol. 1, pp. 174-179. Edited by D. O. Hall \& W. Patz. Dordrecht, The Netherlands: D. Riedel Publishing Company.

Jouanneau, Y., Wong, B. \& Vignais, P. M. (1985). Stimulation by light of nitrogenase synthesis in cells of Rhodopseudomonas capsulata growing in $\mathrm{N}$ limited continuous cultures. Biochimica et biophysica acta 808, 149-155.

Kimball, A. W. (1961). Confidence intervals for recombination experiments with microorganisms. Biometrics 17, 150-152.

Kondorosi, A., Kiss, G. B., Forrai, T., Vincze, E. \& Banfalvi, Z. (1977). Circular linkage map of Rhizobium meliloti chromosome. Nature, London 268 , 525-527.

LAURELL, C. B. (1965). Antigen-antibody crossed immunoelectrophoresis. Analytical Biochemistry 10, 358-361.

LENNOX, E. S. (1955). Transduction of linked genetic characters of the host by bacteriophage P1. Virology 1, 190-206.

MAGASANIK, B. (1982). Genetic control of nitrogen assimilation in bacteria. Annual Review of Genetics 16, 135-168.

MARRS, B. (1974). Genetic recombination in Rhodopseudomonas capsulata. Proceedings of the National Academy of Sciences of the United States of America 71, 971-973.

Meynell, G. G. \& Meynell, E. (1970). Theory and Practice in Experimental Bacteriology, pp. 257-259. Cambridge: Cambridge University Press.

Pühler, A., Aguilar, M. O., Hynes, M., Muller, P., Klipp, W., Priefer, U., Simon, R. \& Weber, G. (1984). Advances in the genetics of free-living and symbiotic nitrogen fixing bacteria. In Advances in Nitrogen Fixation Research, pp. 609-619. Edited by C. Veeger \& W. E. Newton. The Hague \& Pudoc, Wageningen: Martinus Nijhoff/Dr W. Junk.

Rice, D., Mazur, B. J. \& Haselkorn, R. (1982). Isolation and physical mapping of nitrogen fixation genes from the cyanobacterium Anabaena 7120. Journal of Biological Chemistry 257, 1315713163.

Roberts, G. P. \& BriLl, W. J. (1981). Genetics and regulation of nitrogen fixation. Annual Review of Microbiology 35, 207-235.

Rosenberg, C., Casse-Delbart, F., Dusha, I., David, M. \& Boucher, C. (1982). Megaplasmids in the plant-associated bacteria Rhizobium meliloti and Pseudomonas solanacearum. Journal of Bacteriology 150, 402-406.
Ruvkun, G. B. \& Ausubel, F. M. (1981). A general method for site-directed mutagenesis in prokaryotes. Nature, London 289, 85-88.

Scolnix, P. A., Virosco, J. \& Haselkorn, R. (1983). The wild-type gene for glutamine synthetase restores ammonia control of nitrogen fixation to $\mathrm{Gln}^{-}(\mathrm{g} \ln \mathrm{A})$ mutants of Rhodopseudomonas capsulata. Journal of Bacteriology 155, 180-185.

SCOTt, D. B., Court, C. B., Ronson, C. W., Watson, J. M., SCHOFIELD, P. R. \& SHINE, J. (1984). Organization of nodulation and nitrogen fixation genes on a Rhizobium trifolii symbiotic plasmid. Archives of Microbiology 139, 151-157.

Sistrom, W. R. (1977). Transfer of chromosomal genes mediated by plasmid R68.45 in Rhodopseudomonas sphaeroides. Journal of Bacteriology 131, 526-532.

TAYlor, D. P., Cohen, S. N., Clark, W. G. \& Marrs, B. L. (1983). Alignment of genetic and restriction maps of the photosynthetic region of the Rhodopseudomonas capsulata chromosome by a conjugation-mediated marker rescue technique. Journal of Bacteriology 154, 580-590.

Vignais, P. M., Colbeau, A., Willison, J. C. \& JoUANNEAU, Y. (1985). Hydrogenase, nitrogenase and hydrogen metabolism in the photosynthetic bacteria. Advances in Microbial Physiology 26, 155234.

VOGEL, H. J. \& BONNER, D. M. (1956). Acetylornithinase of Escherichia coli: partial purification and some properties. Journal of Biological Chemistry 218, 97106.

WALL, J. D. \& Braddock, K. (1984). Mapping of Rhodopseudomonas capsulata nif genes. Journal of Bacteriology 158, 404-410.

WALL, J. D. \& GEST, H. (1979). Derepression of nitrogenase activity in glutamine auxotrophs of Rhodopseudomonas capsulata. Journal of Bacteriology 137, 1459-1463.

Wall, J. D., Love, J. \& QuinN, S. P. (1984). Spontaneous $\mathrm{Nif}^{-}$mutants of Rhodopseudomonas capsulata. Journal of Bacteriology 159, 652-657.

Weaver, P. F., Wall, J. D. \& Gest, H. (1975). Characterization of Rhodopseudomonas capsulata. Archives of Microbiology 105, 207-216.

Weinman, J. J., Fellows, F. F., Gersshoff, P. M., SHINE, J. \& SCOTT, K. F. (1984). Structural analysis of the genes encoding the molybdenum-iron protein of nitrogenase in the Parasponia rhizobium strain ANU289. Nucleic Acids Research 12, 8329-8344.

Willison, J. C. \& Vignais, P. M. (1982). The use of metronidazole to isolate $\mathrm{Nif}^{-}$mutants of Rhodopseudomonas capsulata, and the identification of a mutant with altered regulatory properties of nitrogenase. Journal of General Microbiology 128, 30013010.

Yen, H. C. \& MARRS, B. (1976) Máp of genes for carotenoid and bacteriochlorophyll biosynthesis in Rhodopseudomonas capsulata. Journal of Bacteriology 126, 619-629.

Youvan, D. C., Elder, J. T., Sandlin, D. E., Zsebo, K., Adler, D. P., Panopoulos, N. J., Marrs, B. L. \& HeARST, J. E. (1982). R-prime site directed transposon $\operatorname{Tn} 7$ mutagenesis of the photosynthetic apparatus in Rhodopseudomonas capsulata. Journal of Molecular Biology 162, 17-41. 